\title{
KING FUAD'S VISIT TO THE INDUSTRIAL AND Educational Centres in Manchester in 1927
}

\section{ASAAD A. ZAKI \\ FACULtY OF TOURISM AND Hotels, UNIVERSITY OF SADAT City, EgyPT}

\begin{abstract}
King Fuad paid his first state visit to Britain in 1927. Through this visit, British and Egyptian officials had high hopes to restore the friendliness between Egypt and Britain. It might lead to a general settlement of the reserved points since 1922 which prevented full harmony between Egypt and Britain after the unilateral Declaration of 28 February 1922. The visit had not only a political purpose, but also it had other intentions; the King visited a selection of Manchester educational and industrial centres, most of these industrial entities had interests in the Egyptian cotton industry.

Manchester was one of the centres of the commerce and of the manufacture of a product representing one of the important resources of Egypt, the Egyptian cotton. The study could contribute a more detailed understanding of the efforts that had been done by the British and the Egyptian Governments to conclude a treaty of friendship, and it could add an additional detail of the Egyptian foreign policy and its involvement in the economic and educational matters during the reign of King Fuad.

The primary concern of this research is to investigate in detail the purpose of the royal visit to Britain in general and to Manchester in particular, to expose the visit program, the places which were visited by the King in Manchester, why these places were specifically selected for the royal visit, and what was the role of the Egyptian students in the University of Manchester during that visit.

This paper seeks to unearth data and stories specific to the visit mainly from the primary sources represented in the documents of Records of Victoria University of Manchester. These accounts are valuable as contemporary records of the event. It appears that these documents have not been previously consulted to tell the story of the Royal visit to Manchester.
\end{abstract}


KEYWORDS: King Fuad's visit to Britain in 1927, Fuad's visit to Manchester in 1927, Cotton Industry, The University of Manchester.

\section{INTRODUCTION}

The visit of King Fuad (r. 1917-1936) to Britain in July 1927, the first state visit to Great Britain, seemed to be an attempt to restore the friendliness between Egypt and Britain after the negotiations between the British Prime Minister Lioyd George and Abd Elkhalek Sarwat Pasha, the Egyptian Prime Minister and Minister for Foreign Affairs. The British and Egyptian officials looked forward to making this visit a positive step to a general settlement of the reserved points since 1922 which prevented a political compromise between Egypt and Britain after the unilateral Declaration of 28 February 1922. The City of Manchester received a special attention during the King's visit to Britain because of its interests in the cotton industry. The King visited a selection of Manchester institutions and mills which were interested in the Egyptian cotton.

King Fuad got an invitation to visit the city from the Lord Mayor of Manchester. The King accepted the invitation and visited a representative selection of Manchester educational and industrial centres. Manchester was one of the centres of the commerce and of the manufacture of a product representing one of the important resources of Egypt, the Egyptian cotton. The study could contribute a more detailed understanding of the efforts that had been done by the British and the Egyptian Governments to conclude a treaty of friendship, and it could focus more on the Egyptian foreign policy and its involvement in the economic and educational matters during the reign of King Fuad.

The primary concern of this research is to investigate in detail the purpose of the royal visit to Britain in general and to Manchester in particular, to expose the visit program, the places which were visited by the King in Manchester, why these places were specifically selected for the royal visit, and what was the role of the Egyptian students in the University of Manchester during that visit.

This paper depends mainly on primary sources represented in the documents of Records of Victoria University of Manchester at the Library of the University of Manchester. These accounts are valuable as contemporary records of the event. It appears that these documents 
have not been previously consulted to tell the story of the royal visit to Manchester, in addition to the news which covered the visit of the Egyptian King to Manchester in 1927. It is an event which has not received enough concern by the researchers although it was the first state visit for King Fuad to Britain and it was an attempt to conclude a general settlement of the reserved points since the Declaration of 1922. This research depends on the historical and analytical research methods through interpretation and criticising the relevant sources and presumption of a particular event.

\section{KING FUAD's VISIT TO BRITAIN IN 1927}

The visit of King Fuad to Britain took place at the invitation of King George on 4 July 1927 in a state visit, the first state visit to Great Britain. The visit decision could be interpreted as evidence of the friendliness that had been restored through the negotiations between the British Prime Minister Lloyd George and Abd Elkhalek Sarwat Pasha, the Egyptian Prime Minister and Minister for Foreign Affairs. Official British Opinion assumed that this visit might lead to a general settlement of the reserved points since 1922 which prevented full harmony between Egypt and Britain; on 28 February 1922, the British Government issued unilateral declaration recognizing the independence of Egypt with the reservation of the four points of capital importance for Britain: the security of British communications across Egypt, the defence of Egypt against foreign nations, the protection of foreign residents and native minorities, and the Sudan. ${ }^{1}$ The British claimed that the principal benefit of such declaration was that it might hasten the conclusion of a treaty, while the secondary advantage was the transfer of the responsibility for the internal government of Egypt from British to Egyptian shoulders. ${ }^{2}$

It was not a real independence, the British themselves admitted that it was "a false position" in which "the British Government granted independence to Egypt with one hand and withdrawn the boon with the other". ${ }^{3}$ British press reported that the presence of King Fuad in London would be a good opportunity to conclude a formal alliance with Egypt and to restore complete independence to Egypt; the British claimed that they intended in the Declaration of 1922 an entire withdrawal from the intervention in Egyptian domestic affairs

\footnotetext{
${ }^{1}$ Lanver Mak, The British in Egypt: Community, Crime and Crises 18821922 (London: I. B. Tauris, 2012), 240.

${ }^{2}$ Great Britain and Egypt, The Economist, July 9, 1927, 52.

${ }^{3}$ King Fuad's Visit, The Manchester Guardian, July 4, 1927, 8.
} 
as soon as the Egyptian Government could protect the British interests in the region specially the imperial communication through the Suez Canal and the British commerce in Egypt. The British praised the efforts of Sarwat Pasha in convincing Wafd Party that the best method of settling the Egyptian problem was by a friendly agreement with Britain which was regarded in London as a diplomatic important event after five years of delay. ${ }^{4}$

The Manchester Guardian considered this visit an indication of the British and Egyptian desire to place their relations upon a permanent footing of friendliness and stability describing the visit by "an excellent beginning" which needs more efforts through systematic negotiations. ${ }^{5}$ Daily Mail reported that this visit was a sign that Anglo-Egyptian relations were, at that time, better than they had been for some time and "a more hopeful era has now begun."

The British Government considered this visit a good opportunity to show to the Egyptian people the cordiality with which Britain would honour the sovereign independence of Egypt; King Fuad was received with the full honours due to a reigning King. ${ }^{7}$ The Prince of Wales, acting for King George, met him at Dover and escorted him to London. ${ }^{8}$ At 3 p.m., when the King arrived at the Victoria Station, the Egyptian National Anthem was played. King George, other members of the Royal Family, the Prime Minister, Stanley Baldwin, and the Foreign Secretary, Austin Chamberlain met King Fuad at the platform. ${ }^{9}$

The Egyptian King was convoyed to Buckingham Palace where he stayed for three days. The wives and daughters of some of the notable men took part in the reception wearing resplendent uniform. The Lord Mayor of London with his sheriffs, the Mayor of Westminster,

\footnotetext{
${ }^{4}$ An Alliance with Egypt: Proposed British Offer," The Observer, June 19, 1927, 17.

${ }^{5}$ King Fuad's Visit, The Manchester Guardian, July 4, 1927, 8.

${ }^{6}$ King Fuad's Visit, Daily Mail, July 5, 1927, 10.

${ }^{7}$ Memorandum by the Secretary of State for Foreign Affairs on 13 July 1927, Papers Regarding Negotiations for a Treaty of Alliance with Egypt, presented by the Secretary of State for Foreign Affairs to Parliament by Command of his Majesty, London, 1928, 3.

${ }^{8}$ Realising a Cherished Desire: King Fuad Visiting England, Illustrated London News, July 9, 1927, 57.

${ }^{9}$ King Fuad: Arrival in London Tomorrow, The Observer, July 3, 1927, 17.
} 
and other officials wore their black velvet court suits. ${ }^{10}$ The interesting thing from a diplomatic point of view is that Austin Chamberlain, the British Foreign Secretary, would meet Sarwat Pasha, the last occasion when a British Foreign Secretary met the Egyptian Prime Minister was when Ramsay McDonald met Saad Zaghlul Pasha in 1924 in order to discuss the Egyptian claim to the Sudan. ${ }^{11}$

King Fuad's own suite included Abd Elkhalek Sarwat Pasha, Prime Minister and Minister for Foreign Affairs; Said Zoulfikar Pasha, Grand Chamberlain; Mohammed Shahin Pasha, Private Physician and Under Secretary of State for Public Health; Amin Anis Pasha, Deputy Chief of the Royal Cabinet; Ahmed Mohammed Hassanein Bey, First Chamberlain; and Achille Sekaly Bey, Director of the European Service of the Council of Ministers. ${ }^{12}$

An Anglo-Egyptian draft treaty was signed in London on 18 July 1927 aiming to end the British military occupation of Egypt within ten years and intending to transform the protectorate into a treaty of friendship and alliance. According to this draft treaty, Egypt was not allowed to conclude an agreement with a foreign power which might be detrimental to the British interests, the Egyptian Government was agreed to the appointment of a British adviser to the Egyptian Government and keeping all the British officials serving in the Egyptian public security and police. ${ }^{13}$ The Egyptian Government could not sign this treaty; the Egyptian Prime Minister claimed that his Government was compelled to take such a decision by the Wafd who rejected it because they thought that there would be significant British reservations. ${ }^{14}$

${ }^{10}$ State Visit of the King of Egypt: London's Hearty Welcome, The Manchester Guardian, July 5, 1927, 11.

${ }^{11}$ Robert A. Hill, The Marcus Garvey and Universal Negro Improvement Association Papers: Volume V September 1922 - August 1924 (California: University of California Press, 1986), 733.

${ }^{12}$ Arrival at Dover: Welcomed by the Prince of Wales," The Manchester Guardian, July 5, 1927, 14.

${ }^{13}$ Counter-draft approved by His Majesty's Government on 28 July 1927, Papers Regarding Negotiations for a Treaty of Alliance with Egypt, presented by the Secretary of State for Foreign Affairs to Parliament by Command of his Majesty, London, 1928, 9.

${ }^{14}$ Telegram from Lord Lioyd to Sir Austin Chamberlain, March 1, 1928, Papers Regarding Negotiations for a Treaty of Alliance with Egypt, 


\section{The King's Visit to Industrial Centers in Manchester}

The City of Manchester received a special attention during the King's visit to Britain because of its interests in the cotton industry. ${ }^{15}$ The Lord Mayor of Manchester conveyed an invitation that the King Fuad should visit Manchester during his visit to England; he said that when he was informed that the King of Egypt intended to visit England, he felt that the business community of Manchester would take the liveliest interest in this visit because of the close connection of the Manchester trade with the cotton production in Egypt. ${ }^{16}$

King Fuad accepted this invitation because of the unique circumstances which linked this county with Egypt; the city of Manchester was one of the centers of the commerce and of the manufacture of a product representing one of the important resources of Egypt, it was the Egyptian cotton. It was arranged that he would visit a representative selection of Manchester institutions and mills which were interested in the sale or utilization of Egyptian cotton. ${ }^{17}$ There was a press interest in the King's visit months before the proposed visit; the Manchester Guardian reported that it was expected that King Fuad would pay visits to some cotton centres in Manchester before leaving England. ${ }^{18}$

The visit included a number of industrial and educational centres of the City of Manchester. The King paid visits to the industrial centres because of its supremacy in the textile industries to show the whole series of processes through which the raw cotton goes from the breaking of the bales to the spinning of the finest counts, to see how the yarns were made into fabrics "which no other manufacturing community in the world can excel" according to the Manchester Guardian description. ${ }^{19}$ The King hoped the result of his visit would

presented by the Secretary of State for Foreign Affairs to Parliament by Command of his Majesty, London, 1928, 61.

Sania Sharawi Lanfranchi, Casting off the Veil: The Life of Huda Shaarawi, Egypt's First Feminist (London: I. B. Tauris, 2015), 155.

${ }^{15}$ People \& their Doings: King Fuad's Visit, Daily Mail, May 14, 1927, 10.

${ }^{16}$ The King of Egypt in Manchester: Assurances to Cotton Industry, The Manchester Guardian, July 20, 1927, 13.

${ }^{17}$ King Fuad's Visit: A Round of Lancashire Institutions, The Manchester Guardian, June 30, 1927, 13.

${ }^{18}$ King Fuad Expected in Lancashire, The Manchester Guardian, April 22, 1927, 13.

${ }^{19}$ The King of Egypt in Manchester: Assurances to Cotton Industry, The Manchester Guardian, July 20, 1927, 13. 
be to increase and strengthen the commercial relations between Egypt and Britain, he claimed that he intended to use all his influence to ensure a supply of clean cotton for England. ${ }^{20}$

Cotton was fundamental part in the British industrial renaissance and Egypt played the vital role in supplying the cotton to the British textile mills. ${ }^{21}$ During the reign of King Fuad, around 85 percent of the 15.000.000 populations of Egypt depended either directly or indirectly on agricultural activities. Cotton was the main source of cash for farmers and the leading item of export. A large percentage of Egyptian exports were cotton products; from 80 to 90 percent of the Egyptian exports were raw cotton, cottonseed products, or cottonseed. Egypt produced about 1.500 .000 bales of cotton crop annually which made Egypt as one of the leading cotton producers around the world. Egypt was the main source of long-stable cotton in the world; the Egyptian cotton was also characterized by its strength, lustre, and silky appearance. ${ }^{22}$

The Egyptian cotton and its spinners were threatened during that time because of the appearance of artificial silk; the Egyptian cotton was the most affected by the introduction of the new fiber which could cause a certain amount of loss to its spinners and weavers who had to redouble their efforts to produce better fabrics. ${ }^{23}$ One of the main sources of the Egyptian economy during that time needed the personal encouragement of the ruler of Egypt; the International Cotton Congress was held at Cairo in January and February 1927.

The International Cotton Congress was held at Cairo in January and February 1927 under the King's patronage and was organized by the International Federation of Master Spinners and Manufacturers' Association, assisted by the Royal Egyptian Agricultural Society. This conference was considered a bigger affair than the last one held in Egypt before fifteen years; the 1912 Congress included representatives of ten countries and 40 delegates, while the 1927 Congress had representatives of twelve European countries and 107

\footnotetext{
${ }^{20}$ King Fuad's Tour in Lancashire, The Times, July 20, 1927, 11.

${ }^{21}$ Peter H. Bent, Agrarian change and industrialization in Egypt, 18001950, In Proceedings of La Théorie de la Régulation à l'épreuve des Crises Paris 10-12 June (Paris: Institut des Langues et Civilisations Orientales, 2015), 3 .

${ }^{22}$ P. K. Norris, Cotton Production in Egypt, Technical Bulletin, no. 451 (October 1934): 1, 2.

${ }^{23}$ Artificial Silk and Cotton, The Economist, July 23, 1927, 160.
} 
delegates. There was a Royal interest in such conference; before the conference unveiling, King Fuad received Frederick Holroyd, President of the International Cotton Federation, and Arno S. Pearse, General Secretary, to discuss the details of the Congress program and the international outlook in the cotton industry. The conference was held in the Opera House, and it was opened by the King who received the delegates. In the evening of the unveiling day of the conference, the King received the whole delegates and other guests at the Abdin Palace. $^{24}$

The conference provided a prospect to exchange views between the growers and the users of Egyptian cotton which would be mutually beneficial for both parties; it was a good opportunity for co-operation between Egyptian producers and eminent representatives of the British cotton industry. According to the wishes formed by the congress, King Fuad claimed that strict measures continued to be taken to avoid the mixing of the various qualities of grain or cotton, while more specialists engaged to the research intending to fight the parasites of cotton. ${ }^{25}$ These observations led to the King's acceptance of the invitation to visit Manchester and other districts around it which had pioneer entities interested in cotton industry.

The King arrived at the boundary of Manchester at 4.45 p.m. on Tuesday 19 July 1927 . He was received at the Manchester boundary by the Chief Constable, John Maxwell, and a detachment of mounted police. ${ }^{26}$ The King was accompanied in Manchester by several officials of his suite; Said Zoulfikar Pasha, Grand Chamberlain; Mohammed Shahin Pasha, Private Physician and Under Secretary of State for Public Health; Amin Anis Pasha, Deputy Chief of the Royal Cabinet; Ahmed Mohammed Hassanein Bey, First Chamberlain; Achille Sekaly Bey, Director of the European Service of the Council of Ministers; and Ilias Ismail, the Egyptian Consul at Liverpool. ${ }^{27}$

\footnotetext{
${ }^{24}$ Cotton Congress: King Fuad and the Visitors, The Manchester Guardian, July 27, 1927, 16.

${ }^{25}$ The King of Egypt in Manchester: Assurances to Cotton Industry, The Manchester Guardian, July 20, 1927, 13; King Fuad's Tour in Lancashire, The Times, July 20, 1927, 11.

${ }^{26}$ Visit of his Majesty the King of Egypt: Official Program, p. 2, Records of Victoria University of Manchester, the University of Manchester Archives, the Library of the University of Manchester, Manchester, UK.

${ }^{27}$ King Fuad's Visit to Manchester: Guest of Lord Mayor at the Town Hall, The Manchester Guardian, July 14, 1927, 13.
} 
The King was genially received in Manchester City; there was a thick lining of spectators along the way from the city boundary to Albert Square to cheer the King, and of every cheer the King made graceful acknowledgement. ${ }^{28}$

Alderman J. H. Swales, the Lord Mayor; the Lady Mayoress; P. M. Heath, the Town Clerk; Alderman Miles E. Mitchell, the Deputy Mayor; and Alderman Fox, ex-Lord Mayor were waiting to receive the King. ${ }^{29}$ The Lord Mayor welcomed the King and conducted him to the residential apartments where he and his suite were to stay during the visit. A ceremonial welcome was extended in the evening in the Council Chamber during which an address was presented to the King. ${ }^{30}$

The King and his suite were entertained at a banquet in the Town Hall at night. There were about 350 guests. The Lord Mayor was present and there were present almost all the aldermen, councillors of the city, the Mayor and Mayoress of Salford, many of the consuls serving in Manchester, the Vice-Chancellor of the University of Manchester and others. ${ }^{31}$

P. M. Heath presented an address to the King in the Town Hall on behalf of the Manchester City; it referred to the inter-relation of British and Egyptian commerce and recalled the interest of the King in the proceedings of the International Cotton Congress held in Egypt in January and February 1927. The address praised the King's concern towards the British merchants and traders who were resident in Egypt or had business relations with Egypt. The Town Clerk praised the King's interest in the advancement of higher education and science and signified the extensive facilities for education which were provided in the University of Manchester and John Rylands Library and he believed that they would meet the King's approval and encouragement. King Fuad replied that Manchester was well known to him and his people and he appreciated Manchester's deserved position as a commercial centre indicating that Egypt and

\footnotetext{
${ }^{28}$ The King of Egypt in Manchester: Assurances to Cotton Industry, The Manchester Guardian, July 20, 1927, 13.

${ }^{29}$ Visit of his Majesty the King of Egypt: Official Program, p. 2, Records of Victoria University of Manchester, the University of Manchester Archives, the Library of the University of Manchester, Manchester, UK.

${ }^{30}$ The King of Egypt in Manchester: Assurances to Cotton Industry, The Manchester Guardian, July 20, 1927, 13.

${ }^{31}$ King Fuad's Visit, the Near East and India, July 28, 1927, 106.
} 
Manchester had common interests. He praised the endurance of the Egyptian peasants facing the radiant weather to ensure the necessary energy and hard work for the cultivation of cotton whose advantages and superiority the British manufacturers had long appreciated. ${ }^{32}$

King Fuad expressed his pleasure to visit Lancashire and Manchester in particular because Manchester was the place where Egypt had the important buyers of cotton which represented an important resource of Egypt. ${ }^{33}$ The Lord Mayor announced that the King handed him $£ 400$ for distribution among the poor of Manchester, "It will give me the greatest pleasure and pride to act as administrator of that fund." 34

\section{KING FUAD'S Visit TO THE UNIVERSITY OF MANCHESTER AND THE ROYAL EXCHANGE}

King's visit to Manchester included a visit to the main educational centre in the city; the University of Manchester. King Fuad paid a special attention in the educational matters in Egypt; The King was a patron of Al-Azhar, the Geographical Society, the Arabic Language Academy, the Egyptian Medical Society, the Coptic Museum, and the Museum of Islamic Art. The international postal, cotton, and medical congresses were held under his patronage and sponsorship. ${ }^{35}$

There was a general desire in Egypt in 1906 for the establishment of secular university; the university of which King Fuad remained President until 1913 "fulfilling his task with sound judgment". He gave a special attention to the Geographical Society of Egypt which was founded by Khedive Ismail in 1875. It almost ceased to function by 1914; Prince Fuad revised its status and brought its program up to date. The International Geographical Congress was held in Cairo in 1925 during the reign of King Fuad.

When Fuad came to throne, he devoted closer attention to educational matters such as the reform and the improvement of Al Azhar University; he acquired land around the old buildings to construct comfortable classrooms with desks and benches instead of the lessons with conflicting voices of many teachers addressing classes close to

\footnotetext{
${ }^{32}$ The King of Egypt in Manchester: Assurances to Cotton Industry, The Manchester Guardian, July 20, 1927, 13.

${ }^{33}$ King Fuad's Tour in Lancashire, The Times, July 20, 1927, 11.

${ }^{34}$ The King of Egypt in Manchester: Assurances to Cotton Industry, The Manchester Guardian, July 20, 1927, 13.

${ }^{35}$ Donald Malcolm Reid, Cairo University and the Making of Modern Egypt (Cambridge: Cambridge University Press, 2002), 71.
} 
each other in the great mosque. King Fuad became a Member's Correspondant of the Academie des Inscriptions et Belles Lettres in Paris in 1927, he received honorary degrees of Doctor of the University of Prague and of the University of Geneva in June $1929 .^{36}$

It was arranged for King Fuad to visit the University of Manchester on 20 July 1927 during his stay in Lancashire. Walter H. Moberly, the Vice-Chancellor of the University sent an invitation to members of the University Court and Senate to be present at the university to welcome King Fuad. ${ }^{37}$

On Wednesday 20 July 1927, the program opened with a visit to the University; the King went to the university soon after ten O'clock together with his suite, Alderman J. H. Swales, the Lord Mayor; P. M. Heath, the Town Clerk; John Maxwell, the Chief Constable; and members of the Manchester City Council, they travelled slowly in open cars, thousands of people lined the streets to cheer the King. ${ }^{38}$

The King was received at the university by W. H. Moberly, the ViceChancellor and A. H. Worthington, the Chairman of the Council. ${ }^{39}$ Although most of the students were gone away for the long vacation, a goodly number of students were present to receive the King at their university; the King was received by thirty of Egyptian students who were studying at the university, they came to render their respect. Some of these students wore fezzes, some bare-headed, but all were bearing a green ribbon, emblem of the Manchester Egyptian Students' Association. ${ }^{40}$ It was a memorable occasion for the Egyptian students in the university. The Egyptian students' spokesman was A. A. Sabry who convoyed their loyal greetings and welcome and expressed their happiness to see the beloved person of

\footnotetext{
${ }^{36}$ King Fuad's Visit: The Man and his Work, The Observer, July 21, 1929, 13.

${ }^{37}$ Walter H. Moberly, the Vice-Chancellor of the University of Manchester, invitation to the members of the University Court and Senate on 7 July 1927, Records of Victoria University of Manchester, the University of Manchester Archives, the Library of the University of Manchester, Manchester, UK.

${ }^{38}$ Visit of his Majesty the King of Egypt: Official Program, p. 2, Records of Victoria University of Manchester, the University of Manchester Archives, the Library of the University of Manchester, Manchester, UK.

${ }^{39}$ Visit of his Majesty King Fuad: Wednesday July $20^{\text {th }} 1927$, Records of Victoria University of Manchester, the University of Manchester Archives, the Library of the University of Manchester, Manchester, UK.

${ }^{40}$ King Fuad's Visit, the Near East and India, July 28, 1927, 106.
} 
the King. The students in their address expressed their admiration for the King's interest in the centres of learning and industry; this interest would be "an inspiration to the Egyptian people to strive on to those high ideals which your Majesty has set before them." The address added "this day of your Royal visit will be a stimulant throughout our future careers and will be held in everlasting remembrance by your Majesty's most faithful subjects in this university."41

They asked permission to offer a token of their joy in welcoming their King to Manchester. The King accepted the token with a smile of pleasure; the token was an engraved silver box, Mohammed Hamdy, the Egyptian student, handed it to the King asking him to accept "our love and thoughts, embedded in this silver case." 42
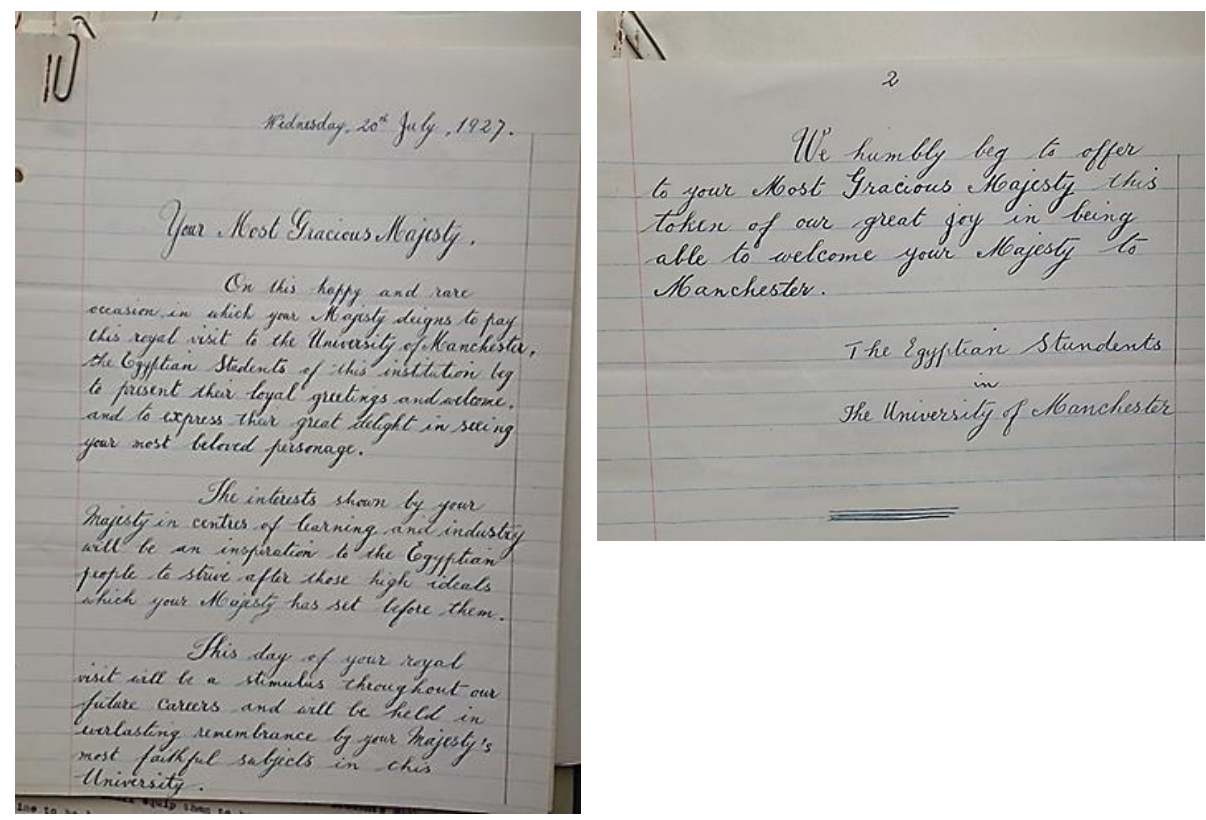

The address of the Egyptian students in the University of Manchester on 20 July $1927 .^{43}$

\footnotetext{
${ }^{41}$ The address of the Egyptian students in the University of Manchester on 20 July 1927, Records of Victoria University of Manchester, the University of Manchester Archives, the Library of the University of Manchester, Manchester, UK.

${ }^{42}$ Address of Mohammed Hamdy, the Egyptian student, on behalf of the Manchester Egyptian Students' Association on 20 July 1927, Records of Victoria University of Manchester, the University of Manchester Archives, the Library of the University of Manchester, Manchester, UK.

${ }^{43}$ The address of the Egyptian students in the University of Manchester on 20 July 1927, Records of Victoria University of Manchester, the University
} 
While the King passing on to the Council Chamber, shouts of "long live King Fuad, long live Great Britain" were heard. The ViceChancellor read an address of welcome for King Fuad, he said that the King is the ruler of a country which was not only linked to Britain by ties of business and friendship, but also is the home of the earliest and longest civilization known to history, which affected the arts and sciences studied in that university. The Vice-Chancellor considered the presence of Egyptian students at the University of Manchester an evidence of the links which bound the university with "the Egypt of the present," while the ancient Egyptian collection in the University Museum as an evidence of Manchester's interest in "the Egypt of the past." Moberly claimed that the aim of the university was to promote research on issues affecting the technical problems of industry, and to give training to all its students to equip them to be useful citizens and to be leaders in commerce or industry.

Moberly promised the King that his subjects who were joining the University of Manchester "will be found to be so equipped." "The King and his suite were then conducted through the museum where they saw many objects of the Ancient Egyptian civilization, they looked with much interest on the ancient Egyptian relics, this visit caused the museum to be more prominent. ${ }^{45}$

They went to see the John Rylands Library; Henry Guppy, the Librarian, received the King and showed him the principal treasures of the library, several the collection items such as papyri, manuscripts, and selected books were laid out for the inspection of the King. These items included a number of ancient Persian and Arabic manuscripts, the King was particularly interested in an edition of the Quran; this book was the biggest book in the library, nearly a foot thick and its covers are about two feet by three feet. ${ }^{46}$ The King

of Manchester Archives, the Library of the University of Manchester, Manchester, UK.

${ }^{44}$ Address of welcome spoken by the Vice-Chancellor on the occasion of the visit of his Majesty King Fuad of Egypt to the University of Manchester on Wednesday, July $20^{\text {th }} 1927$, Records of Victoria University of Manchester, the University of Manchester Archives, the Library of the University of Manchester, Manchester, UK.

${ }^{45}$ Samuel J. M. M. Alberti, Nature and Culture: Objects, Disciplines and the Manchester Museum (Manchester: Manchester University Press, 2009), 73.

${ }^{46}$ King Fuad's Visit, the Near East and India, July 28, 1927, 107. 
displayed a particular interest in the research on the issues affecting the technical problems of the cotton industry. ${ }^{47}$

The Lord Mayor of Manchester and the Town Hall Committee were satisfied with the arrangements which were made by the ViceChancellor of the university for the reception of King Fuad during the visit; the Lord Mayor thanked W. H. Moberly for the good preparations made for the inspection of the university on the occasion of Fuad's visit to the city, he informed him that these arrangements assisted in making the visit a success. ${ }^{48}$ Moberly replied "It was a pleasant function."

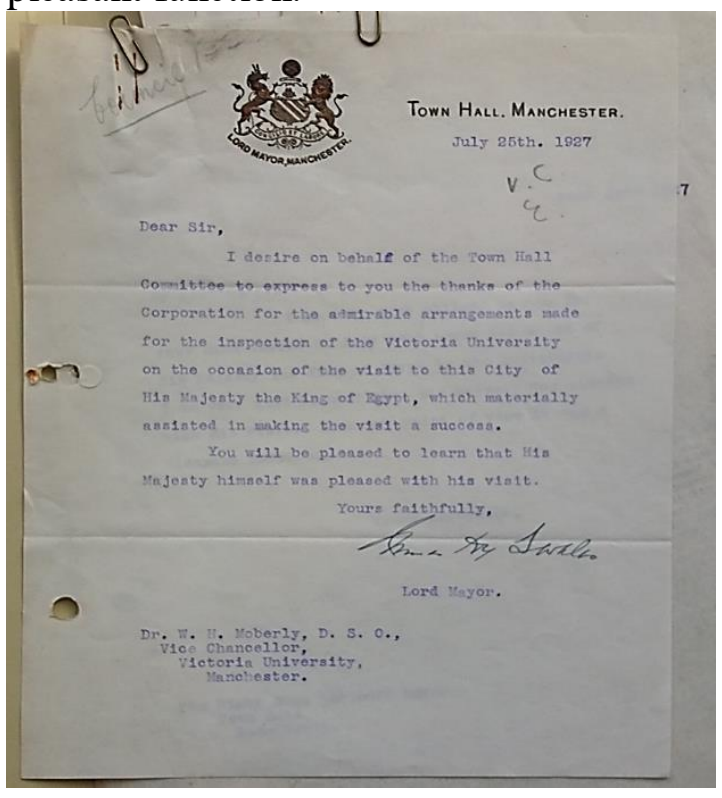

A letter of thanks from the Lord Mayor of Manchester to the Vice

Chancellor of the University of Manchester. ${ }^{50}$

${ }^{47}$ King Fuad in Lancashire, Daily Mail Atlantic Edition, July 22, 1927, 12.

${ }^{48} \mathrm{~J}$. H. Swales, the Lord Mayor of Manchester, a letter to W. H. Moberly, the Vice-Chancellor of the University of Manchester on 25 July 1927, Records of Victoria University of Manchester, the University of Manchester Archives, the Library of the University of Manchester, Manchester, UK.

${ }^{49} \mathrm{~W}$. H. Moberly, the Vice-Chancellor of the University of Manchester, a letter to J. H. Swales, the Lord Mayor of Manchester on 25 July 1927, Records of Victoria University of Manchester, the University of Manchester Archives, the Library of the University of Manchester, Manchester, UK.

${ }^{50}$ J. H. Swales, the Lord Mayor of Manchester, a letter to W. H. Moberly, the Vice-Chancellor of the University of Manchester, on 25 July 1927, Records of Victoria University of Manchester, the University of Manchester Archives, the Library of the University of Manchester, Manchester, UK. 
At 2.00 p.m. of the same day, the King with his suite, accompanied by the Lord Mayor, the Deputy Mayor, and the Chief Constable visited the Royal Exchange, which was the largest in the world to trade in raw cotton, where they found substantial crowds awaited their arrival $;{ }^{51}$ the entrance was decorated for the visit with an awning of green and white with flowers on either side of the staircase. The King was received by Arthur Haworth, the Chairman of the Exchange who presented to the King the officers of the Royal Exchange. ${ }^{52}$

Arthur Haworth read an address of welcome to the King on behalf of the members, he wished that the friendship and goodwill which existed between Egypt and Britain might ever continue and this visit might improve more interest in the spinning industry upon which the prosperity of both countries depended. The King replied in French, he thanked the members of the Royal Exchange for their cordial reception and confirmed on the significance of cotton as a main source of income to Egypt and of prosperity of the Egyptians, ${ }^{53}$ it would be natural that no effort should be spared not only to develop its cultivation, to improve its quality and scientifically to defend it against the parasites and epidemics to which it was exposed, but also to satisfy the spinners and manufacturers and to help the Egyptian producer to get a fair price equivalent to their work and efforts. The King indicated that a notable progress had been achieved since the cotton congress which was held in Cairo, this conference offered a good opportunity for the Egyptian producers to contact with the representatives of Manchester spinners and manufacturers. ${ }^{54}$

During this visit, King Fuad conferred upon the Lord Mayor of Manchester and Thomas Flitcroft, the Lord Mayor of Bolton, the Order of the Nile (Kiladat El Nil). Flitcroft appreciated this award and said that he gladly accepted it as honour done to the town of Bolton. The Lord Mayor of Manchester and the Lord Mayor of

\footnotetext{
${ }^{51}$ King Fuad in Lancashire, Daily Mail Atlantic Edition, July 22, 1927, 12.

${ }^{52}$ Visit of his Majesty the King of Egypt: Official Program, p. 2, Records of Victoria University of Manchester, the University of Manchester Archives, the Library of the University of Manchester, Manchester, UK.

${ }^{53}$ King Fuad's Tour in Lancashire, The Times, July 20, 1927, 11.

${ }^{54}$ King Fuad's Busy Day in Lancashire: Greeting from Egyptian Students, The Manchester Guardian, July 21, 1927, 13.
} 
Bolton wore the decoration of the Order of the Nile during a banquet for the King Fuad in the Bolton Town Hall. ${ }^{55}$

The King left the City of Manchester on 21 July 1927 returning to London escorted by mounted police, large crowds lined his route in Manchester, cheered and waved "good-bye." The King asked the Lord Mayor to tell the people of Manchester how much he thanks them for their cordial reception. The train was especially equipped with two saloons for the convenience of the King and his staff. A group of Egyptian students were on the platform, and as the train went out, they raised repeated cries of "Long live King Fuad."

The civic authorities in Manchester were keen to meet King Fuad and to have representatives during the civic banquet for the King. A number of Manchester magistrates protested at the quarterly meeting of the Manchester City Justices on 28 July 1927 against the exclusion of certain of their number from the list of guests at the banquet.57 The Manchester Board of Guardians objected to not inviting them to the public function during Fuad's visit. During the sitting of the Manchester City Council which was held on 3 August 1927, there was a strong protest made against the omission of the Town Hall Committee to send any invitation to representatives of the Board of Guardians to attend the visit of King Fuad to the city. They got a promise that it should not happen again. ${ }^{58}$

They assumed that their complaint was not that they as citizens were ignored, but that the Board as a public body was ignored; they were jealous for the Board dignity. The Chairman of the Board said that they should be recognized and invited during the King's banquet as a representative body; they were elected by the citizens who elected the City Council and therefor they represented the citizens. The Guardians were a representative body covering 25.210 acres with a population of 766.030 and a rateable value of $£ 7.013 .000$, they looked after hospitals, infirmaries, convalescent homes, children's

\footnotetext{
${ }^{55}$ Banquet at Bolton: King Fuad's Decoration for Mayor, The Manchester Guardian, July 21, 1927, 13.

${ }^{56}$ King Fuad Departs: Delight at Manchester's Hospitality, The Manchester Guardian, July 22, 1927, 11.

57 Civic Banquet to King Fuad: Another Protest, The Manchester Guardian, July 29, 1927, 10.

${ }^{58}$ Manchester City Council: Guardians and King Fuad Banquet, The Manchester Guardian, August 4, 1927, 11.
} 
homes, and Poor Law institutions. They employed a staff of nearly 3000 persons during that time; they had chargeable to them. ${ }^{59}$

\section{The King's Visit to Other Industrial Centres AROUnd MANCHESTER}

The King did not only pay a visit to Manchester, but also, he visited other industrial districts around it because of their supremacy in the textile industries. In the course of his tour in Lancashire, Fuad visited, Liverpool, Preston, Bolton and Manchester, he saw various aspects of cotton industry, in which Egypt was largely interested as a source of supply of the raw material.

The King was received in Lime-Street Station in Liverpool by the Lord Mayor of Liverpool and the Egyptian Consul. The King visited the Cotton Exchange where he was presented with an address of welcome by its President, C. S. Hannay. Hannay had confirmed on the point that Lancashire had special ties with the King's country because its mills depended on Egypt for a large quantity of their raw material. He assured the mutual benefit for Egypt, the producer, and Britain, the consumer. The King was presented a golden casket in the form of a bale of Egyptian cotton. ${ }^{60}$

King Fuad paid a visit to Preston on 19 July 1927 and was received by the Lord Mayor passing under an archway formed of bales of Egyptian cotton. The King witnessed the mill of Horrockses Crewdson, and Co. Limited where he was shown the process of manufacturing the Egyptian cotton from the opening of the bales until finishing the cotton as garments. ${ }^{61}$

Fuad was offered an opportunity to see the original mills erected by John Horrocks in 1791 including the spinning wheel on which Horrocks used to spin his yarn. The King handed the Mayor of Preston a cheque for $£ 300$ for the poor and aged people of Preston. ${ }^{62}$

During the International Cotton Congress at Cairo, Thomas Flitcroft, the Lord Mayor of Bolton, and William Howarth, President of the

\footnotetext{
59 Poor Law Guardian Offended: Complaint of Cold-Shouldering, The Manchester Guardian, July 23, 1927, 15.

${ }^{60}$ The King of Egypt: Visit to Lancashire, The Times, July 19, 1927, 17.

${ }^{61}$ King Fuad's Visit, the Near East and India, July 28, 1927, 106.

${ }^{62}$ King Fuad's Tour in Lancashire, The Times, July 20, 1927, 11.
} 
Master Cotton Spinners' Association, invited King Fuad to visit Bolton, the King expressed his pleasure for the invitation. ${ }^{63}$

The King was warmly welcomed by the people of Bolton on 20 July 1927, King Fuad appreciated it, and he had given the poor of the town a cheque for $£ 300 .{ }^{64}$ The King visited the Musgrave Fine Spinning Mill- the largest mill spinning Egyptian cotton - with 450.000 spindles where the Egyptian cotton was spun, woven, finished and dyed. ${ }^{65}$

The King assumed that his visit had given him a proof that he would do all he could to increase the prosperity of his people through striving to increase the production of the Egyptian cotton which meant much to the Bolton community as a Centre of the fine spinning of Egyptian yarns. He believed that Bolton had the most expert workers in the manufacture of cotton. Arthur Howarth thanked King Fuad for the kind welcome which the International Cotton Conference had received in Egypt in January and February 1927. ${ }^{66}$

\section{CONCLUSION}

These observations in this article yield conclusions that address how the visit of King Fuad to Britain in 1927 formed an attempt to conclude an agreement regarding the four reserved points in the Declaration of 1922 which formed a stumbling block in the AngloEgyptian relations. The presence of the King himself together with his Prime Minister in Britain encouraged a draft treaty to be concluded with Britain on 18 July 1927 aiming to end the British military occupation of Egypt within ten years and intending to transform the protectorate into a treaty of friendship and alliance, but it was refused by the Egyptian nationalists as it did not guarantee full Egyptian sovereignty.

The British Government tried to show its respect to the Egyptian State through a cordial reception of its King and honouring the sovereign independence of Egypt; King Fuad was received with the

\footnotetext{
${ }^{63}$ King Fuad Invited to Visit Bolton: Samuel Crompton Centenary, The Manchester Guardian, February 22, 1927, 14.

${ }^{64}$ King Fuad: Guest of the City of London, The Manchester Guardian, July 6, 1927, 14.

${ }^{65}$ King Fuad's Visit to Lancashire: To See Mills at Preston and Bolton, The Manchester Guardian, July 12, 1927, 13.

${ }^{66}$ Banquet at Bolton: King Fuad's Decoration for Mayor, The Manchester Guardian, July 21, 1927, 13.
} 
full honours due to a reigning King which would contribute to the King's stature at home.

It is argued above that the Royal visit had not only a political purpose, but the King had the opportunity to support one of the important resources of Egypt, the Egyptian cotton. King Fuad visited several educational and industrial centres in Manchester and in other districts around it because they represented main centres in the commerce and the manufacture of the Egyptian cotton which was the main source of cash for farmers and the leading item of export. A large percentage of Egyptian exports were cotton products; from 80 to 90 percent of the Egyptian exports were raw cotton, cottonseed products, or cottonseed.

There was a mutual desire among the British business leaders and the Egyptian Government to expand access to each other; the British consumers were keen to communicate with the cotton producers in Egypt, many of those leaders attended the International Cotton Congress which was held at Cairo in January and February 1927. The King and his Government had a desire to expand access to the cotton consumer market in Britain, so, the King accepted the invitation to visit Manchester and other districts around it because of their supremacy in the textile industries.

The visit could be interpreted as a King's blessing to the Cotton agriculture and could send an important message to the British cotton consumers that the King himself guaranteed that no effort should be spared to develop its cultivation, to improve its quality, to satisfy the spinners and manufacturers and to help the Egyptian producers to get a fair price equivalent to their work and efforts.

\section{REFERENCES}

Address of Mohammed Hamdy, the Egyptian student, on behalf of the Manchester Egyptian Students' Association on 20 July 1927, Records of Victoria University of Manchester, the University of Manchester Archives, the Library of the University of Manchester, Manchester, UK.

Address of the Egyptian students in the University of Manchester on 20 July 1927, Records of Victoria University of Manchester, the University of Manchester Archives, the Library of the University of Manchester, Manchester, UK.

Address of welcome spoken by the Vice-Chancellor on the occasion of the visit of his Majesty King Fuad of Egypt to the University 
of Manchester on Wednesday, 20 July 1927, Records of Victoria University of Manchester, the University of Manchester Archives, the Library of the University of Manchester, Manchester, UK.

Alberti, Samuel J. M. M., Nature and Culture: Objects, Disciplines and the Manchester Museum. Manchester: Manchester University Press, 2009.

"An Alliance with Egypt: Proposed British Offer." The Observer, June 19, 1927.

"Arrival at Dover: Welcomed by the Prince of Wales." The Manchester Guardian, July 5, 1927.

“Artificial Silk and Cotton.” The Economist, July 23, 1927.

"Banquet at Bolton: King Fuad's Decoration for Mayor." The Manchester Guardian, July 21, 1927.

Bent, Peter H., "Agrarian change and industrialization in Egypt, 1800-1950." In Proceedings of La Théorie de la Régulation à l'épreuve des Crises, June 10-12, 2015, Paris.

"Civic Banquet to King Fuad: Another Protest" The Manchester Guardian, July 29, 1927.

"Cotton Congress: King Fuad and the Visitors" The Manchester Guardian, July 27, 1927.

Counter-draft approved by His Majesty's Government on 28 July 1927, Papers Regarding Negotiations for a Treaty of Alliance with Egypt, presented by the Secretary of State for Foreign Affairs to Parliament by Command of his Majesty, London, 1928.

"Great Britain and Egypt" The Economist, July 9, 1927.

Hill, Robert A., The Marcus Garvey and Universal Negro Improvement Association Papers: Volume V September 1922 August 1924. California: University of California Press, 1986.

"King Fuad Departs: Delight at Manchester's Hospitality" The Manchester Guardian, July 22, 1927.

"King Fuad Expected in Lancashire" The Manchester Guardian, April 22, 1927.

"King Fuad in Lancashire" Daily Mail Atlantic Edition, July 22, 1927.

"King Fuad Invited to Visit Bolton: Samuel Crompton Centenary" The Manchester Guardian, February 22, 1927.

"King Fuad: Arrival in London Tomorrow" The Observer, July 3, 1927.

"King Fuad: Guest of the City of London" The Manchester Guardian, July 6, 1927. 
"King Fuad's Visit." the Near East and India, July 28, 1927.

"King Fuad's Busy Day in Lancashire: Greeting from Egyptian Students" The Manchester Guardian, July 21, 1927.

"King Fuad's Tour in Lancashire" The Times, July 20, 1927.

"King Fuad's Tour in Lancashire" The Times, July 20, 1927.

"King Fuad's Visit to Lancashire: To See Mills at Preston and Bolton" The Manchester Guardian, July 12, 1927.

"King Fuad's Visit to Manchester: Guest of Lord Mayor at the Town Hall” The Manchester Guardian, July 14, 1927.

"King Fuad's Visit" Daily Mail, July 5, 1927.

"King Fuad's Visit" The Manchester Guardian, July 4, 1927.

"King Fuad's Visit: A Round of Lancashire Institutions" The Manchester Guardian, June 30, 1927.

"King Fuad's Visit: The Man and his Work" The Observer, July 21, 1929.

Lanfranchi, Sania Sharawi. Casting off the Veil: The Life of Huda Shaarawi, Egypt's First Feminist. London: I. B. Tauris, 2015.

Mak, Lanver. The British in Egypt: Community, Crime and Crises 1882-1922. London: I. B. Tauris, 2012.

Malcolm Reid, Donald. Cairo University and the Making of Modern Egypt. Cambridge: Cambridge University Press, 2002.

"Manchester City Council: Guardians and King Fuad Banquet." The Manchester Guardian, August 4, 1927.

Memorandum by the Secretary of State for Foreign Affairs on 13 July 1927, Papers Regarding Negotiations for a Treaty of Alliance with Egypt, presented by the Secretary of State for Foreign Affairs to Parliament by Command of his Majesty, London, 1928.

Moberly, W. H., the Vice-Chancellor of the University of Manchester, a letter to Swales, J. H., the Lord Mayor of Manchester on 25 July 1927, Records of Victoria University of Manchester, the University of Manchester Archives, the Library of the University of Manchester, Manchester, UK.

Moberly, Walter H., the Vice-Chancellor of the University of Manchester, invitation to the members of the University Court and Senate on 7 July 1927, Records of Victoria University of Manchester, the University of Manchester Archives, the Library of the University of Manchester, Manchester, UK.

Norris, P. K., "Cotton Production in Egypt." Technical Bulletin, no. 451, October 1934.

"People \& their Doings: King Fuad's Visit." Daily Mail, May 14, 1927. 
"Poor Law Guardian Offended: Complaint of Cold-Shouldering", The Manchester Guardian, July 23, 1927.

"Realising a Cherished Desire: King Fuad Visiting England." Illustrated London News, July 9, 1927.

"State Visit of the King of Egypt: London's Hearty Welcome." The Manchester Guardian, July 5, 1927.

Swales, J. H., the Lord Mayor of Manchester, a letter to W. H. Moberly, the Vice-Chancellor of the University of Manchester on 25 July 1927, Records of Victoria University of Manchester, the University of Manchester Archives, the Library of the University of Manchester, Manchester, UK.

Swales, J. H., the Lord Mayor of Manchester, a letter to W. H. Moberly, the Vice-Chancellor of the University of Manchester, on 25 July 1927, Records of Victoria University of Manchester, the University of Manchester Archives, the Library of the University of Manchester, Manchester, UK.

Telegram from Lord Lioyd to Sir Austin Chamberlain, March 1, 1928, Papers Regarding Negotiations for a Treaty of Alliance with Egypt, presented by the Secretary of State for Foreign Affairs to Parliament by Command of his Majesty, London, 1928.

"The King of Egypt in Manchester: Assurances to Cotton Industry", The Manchester Guardian, July 20, 1927.

"The King of Egypt: Visit to Lancashire" The Times, July 19, 1927.

Visit of his Majesty King Fuad: Wednesday July $20^{\text {th }} 1927$, Records of Victoria University of Manchester, the University of Manchester Archives, the Library of the University of Manchester, Manchester, UK.

Visit of his Majesty the King of Egypt: Official Program, p. 2, Records of Victoria University of Manchester, the University of Manchester Archives, the Library of the University of Manchester, Manchester, UK. 